\title{
A New Occurrence of Terrestrial Native Iron in the Earth's Surface: The Ilia Thermogenic Travertine Case, Northwestern Euboea, Greece
}

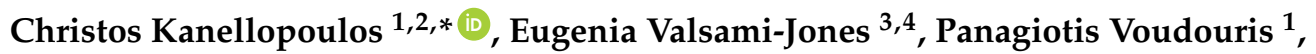 \\ Christina Stouraiti ${ }^{1}$ (1D), Robert Moritz ${ }^{2}$, Constantinos Mavrogonatos ${ }^{1}$ (1) and \\ Panagiotis Mitropoulos ${ }^{1, \dagger}$ \\ 1 Department of Geology and Geoenvironment, National and Kapodistrian University of Athens, \\ Panepistimioupolis Zografou, 15784 Athens, Greece; voudouris@geol.uoa.gr (P.V.); \\ chstouraiti@geol.uoa.gr (C.S.); kmavrogon@geol.uoa.gr (C.M.); pmitrop@geol.uoa.gr (P.M.) \\ 2 Section of Earth and Environmental Sciences, University of Geneva, Rue des Maraichers 13, \\ 1205 Geneva, Switzerland; Robert.Moritz@unige.ch \\ 3 School of Geography, Earth \& Environmental Sciences, University of Birmingham, Edgbaston, \\ Birmingham B15 2TT, UK; e.valsamijones@bham.ac.uk \\ 4 Department of Earth Sciences, Natural History Museum London, Cromwell Road, London SW7 5BD, UK \\ * Correspondence: ckanellopoulos@gmail.com \\ + Professor Panagiotis Mitropoulos has passed away in 2017.
}

Received: 6 April 2018; Accepted: 23 July 2018; Published: 31 July 2018

\begin{abstract}
Native iron has been identified in an active thermogenic travertine deposit, located at Ilia area (Euboea Island, Greece). The deposit is forming around a hot spring, which is part of a large active metallogenetic hydrothermal system depositing ore-bearing travertines. The native iron occurs in two shapes: nodules with diameter 0.4 and $0.45 \mathrm{~cm}$, and angular grains with length up to tens of $\mu \mathrm{m}$. The travertine laminae around the spherical/ovoid nodules grow smoothly, and the angular grains are trapped inside the pores of the travertine. Their mineral-chemistry is ultra-pure, containing, other than Fe, only $\mathrm{Mn}(0.34-0.38 \mathrm{wt} . \%)$ and $\mathrm{Ni}(\leq 0.05 \mathrm{wt} . \%)$. After evaluating all the possible environments where native iron has been reported up until today and taking under consideration all the available data concerning the study area, we propose two possible scenarios: (i) Ilia's native iron has a magmatic/hydrothermal origin i.e., it is a deep product near the magmatic chamber or a peripheral cooling igneous body that was transferred during the early stages of the geothermal field evolution, from high temperature, reduced gas-rich fluids and deposited along with other metals in permeable structural zones, at shallow levels. Later on, it was remobilized and mechanically transferred and precipitated at the Ilia's thermogenic travertine by the active lower temperatures geothermal fluids; (ii) the native iron at Ilia is remobilized from deep seated ophiolitic rocks, originated initially from reduced fluids during serpentinization processes; however, its mechanical transport seems less probable. The native iron mineral-chemistry, morphology and the presence of the other mineral phases in the same thermogenic travertine support both hypotheses.
\end{abstract}

Keywords: native iron; hydrothermal system; thermogenic travertine; serpentinization processes

\section{Introduction}

The occurrence of native elements as authigenic mineral phases in nature is an extremely rare phenomenon. Examples of elements present in the native (zero-valence) state include, among others, $\mathrm{Al}[1,2], \mathrm{Si}[3], \mathrm{Ni}[4], \mathrm{Au}[5,6], \mathrm{Co}$ [7], $\mathrm{Cu}$ and $\mathrm{Ti}$ [8]. Native iron is unstable under the oxygen fugacity conditions prevailing in the Earth's crust and mantle, with a few exceptions [9]. 
Iron is one of the most abundant elements in the Universe and in our planet. It is the 6th most abundant chemical element in the Universe and the 4th in the Earth's crust, which contains about $5 \%$ iron [10]. The inner core of the Earth is composed of Fe, alloyed with small amounts of light elements [11]. Iron belongs to the eighth group of the periodic table, with atomic number 26 and occurs in a wide range of oxidation states, -2 to +6 , with +2 and +3 the most common. It is a reactive element and oxidizes easily. It is strongly magnetic and melts at $1535^{\circ} \mathrm{C}$ [12]. Iron is found in many minerals as major or trace components. Most of it is found combined with oxygen forming Fe-oxide minerals, such as hematite $\left(\alpha-\mathrm{Fe}_{2} \mathrm{O}_{3}\right)$ and magnetite $\left(\mathrm{Fe}_{3} \mathrm{O}_{4}\right)$ [13].

Iron can occur as a native element in reducing environments, but is highly reactive in the presence of oxygen and water. A characteristic example is extraterrestrial (meteoritic) iron, which mainly comes from iron-nickel meteorites, that are preserved by the vacuum of space prior to falling on Earth. Metallic meteorites are composed mainly of Fe-Ni alloys like taenite and kamacite and contain small quantities of other impurities such as cobalt, manganese, tin, chromium, sulfur, carbon, chlorine, copper and phosphorus [14].

However, there are some specific environments on Earth where terrestrial native iron (telluric) can be found, mainly in igneous rocks [15]. Terrestrial iron has also been reported in basalts, ultramafic members of ophiolitic complexes, kimberlite and in hydrothermal systems. Except for serpentinization, in all other cases the terrestrial native iron is formed when magmas interact with carbonaceous crustal material producing extremely reducing conditions.

Regarding the presence of native iron in basalts, the only reported occurrences are from the basalt at Ovifak, Disko Island, Greenland [16-19], from the Bühl basalt, Kessel, Germany [20,21] and from the Khungtukun intrusion, Maimecha-Kotui magmatic province in northern Siberia [22-28]. The most prevailing theory, based on geochemistry of highly siderophile elements and Re-Os isotopic systematics, favours the formation of such occurrences by interaction of basaltic magma with carbon-rich sediments, under low oxygen fugacities $\left(\mathrm{fO}_{2}\right)$ during magmatic crystallization, resulting in the precipitation of native iron, (e.g., [29] and references therein).

Additionally, native iron has been found in layered intrusion and ophiolitic rocks such as serpentinized dunites, peridotites, serpentinites and chromitites. The best known and documented occurrences are from Muskox, Canada [30], the Mina do Abessedo, Portugal [31], Shaman, Baikal [32], Kachkanar, Ural [33], the Vetrenii belt, Baltic shield [34], Josephine, U.S.A. [35], the Sanbagawa belt, central Japan [36], the Maqsad ophiolite, Oman [37], Balangero, Italy [38], the Luobusa ophiolite, southern Tibet [3,39,40], the Ray-Iz ophiolite, Polar Urals [41] and from Skyros island, Greece [42].

Native iron has been identified in diamonds from specific regions or kimberlites [43] such as from the Yakutia kimberlite [44], the Sloan diamonds [45], from the Rio Soriso in association with low-Ni pyrrhotite [46] and the Pandrea-1 pipe in association with ferropericlase and chrome spinel [47], both from the Juina area, Brazil, and from the placer Kankan deposit in Guinea [48].

In geothermal systems, the presence of native iron has been reported only from the Kuril Islands, Russia. Spherical nodules of native iron have been found in a deep geothermal drill [49,50], and Yudovskaya et al. [51] reported the occurrence of native iron in active fumaroles at the Kudryavy volcano, Iturup Island (group of Kuril Islands).

Native iron on Earth is actually not totally pure, but usually contains a noticeable percentage of some other elements, mainly $\mathrm{Ni}(2.44-0.03 \mathrm{wt} . \% \mathrm{Ni}$; [52]). The iron-nickel alloy grains have been described to have either an extra-terrestrial [53] or terrestrial origin [39]. In addition to nickel, the terrestrial iron occurrences also contain other elements such as As, Co, Cu, Mn (see [36,38,41,43,52]), and the extra-terrestrial occurrences may include elements such as $\mathrm{Cr}, \mathrm{Co}, \mathrm{Mn}, \mathrm{Ni}$, $\mathrm{Si}$ (see [39]).

This paper reports, for the first time, an exceptionally rare occurrence of ultra-pure native iron $(\mathrm{Ni} \leq 0.05 \mathrm{wt} . \%)$ from Fe-As-rich thermogenic travertines in the Ilia area, Euboea Island, Greece. The aim of this study is to describe the composition and identify the origin of native iron within the Ilia travertine, on the basis of petrography, multi-analytical mineralogical and geochemical studies and comparisons with other occurrences of native iron elsewhere. 


\section{Geological Setting}

The Ilia area is located in the northwestern part of Euboea Island, Greece (Figure 1). The study area is located at the western extremity of the North Anatolian Fault and in a back-arc position with respect to the South Aegean Active Volcanic Arc [54-56]. It is one of the most neo-tectonically active areas in Greece dominated by extensional tectonics similar to the rest of the Aegean Sea.

The northwestern Euboea island comprises a lower series of Permian-Triassic volcanoclastic rocks overlying a pre-middle to middle Carboniferous metamorphic basement, which are in turn overlain by middle Triassic shallow marine clastic and carbonate rocks intercalated with volcanic rocks best developed at the southeast part of Aedipsos town $[57,58]$. On top of this sequence, Jurassic limestones and late Jurassic to early Cretaceous ophiolitic rocks occur (mainly metabasites and serpentinites, [57-59], Figure 1). The Palaeozoic and Mesozoic sequences were folded or imbricated as a result of two main tectonic events (Alpine and Eo-Alpine). In the broad area of northern Euboea, lignite layers have been identified as intercalations within Neogene-lower Pleistocene lake sediments [60].

The central part of the Euboean Gulf is occupied by the Plio-Pleistocene volcanic center of Lichades Islands [54,61] and comprises 0.5 Ma (K-Ar, [62]) trachyandesitic lava flows. Magma emplacement took place along major tectonic structures in the area [63]. Karastathis et al. [64] showed that there is a magma chamber at depths 7-8 km, under the North Euboean Gulf. Innocenti et al. [65], based on $\mathrm{Sr}-\mathrm{Nd}-\mathrm{Pb}$ isotopic data, related this volcanic center with the large volcanic belt that developed north of the Pelagonian-Attic-Cycladic-Menderes massifs, encompassing a 35 Ma timespan, which is widespread over a large area from NW Greece-Macedonia to the Aegean-western Anatolia. According to the above references, the Lichades volcanic products are orogenic in character and partially contemporaneous with the south Aegean active volcanic arc, but with different geochemical features, related to distinct magma sources (e.g., lithospheric mantle wedge and a depleted asthenospheric mantle wedge north and south of the Pelagonian-Attic-Cycladic-Menderes massifs, respectively).

At the northwestern part of Euboea Island and the neighboring area of Sperchios (mainland), several hot springs occur (Figure 1), considered to be part of a single hydrothermal system, which is controlled by active tectonics, and supplied with heat by the deep magma chamber [66]. Euboea's hot springs are characterized by a mixture of seawater and deep magmatic fluid with only limited meteoric water contribution [66]. Another salient feature of them is the dominance of thermogenic travertine deposition [67-70]. Kanellopoulos et al. [66] described active metallogenetic processes at the system leading to ore-bearing travertines including Ilia's travertine.

In the Ilia area, an artesian borehole, which crosscuts metamorphic rocks, is venting hot water [71] and it is depositing $\mathrm{Fe} \pm$ As rich travertine ([66,69], Figure 2A,B). Ilia is located on a marked bend of the marginal fault system, where the average strike changes from SE-NW to E-W (or ENE-WSW). That deep fault system is being used for the circulation of the hydrothermal fluid.

\section{Materials and Methods}

Two polished sections including metallic grains and the host travertine were first studied under stereomicroscope and optical microscope. SEM-EDS analysis was carried out using a Jeol JSM 5600 SEM instrument (JEOL USA, Inc.: Peabody, MA, USA), equipped with an Oxford ISIS 300 (Oxford Instruments: Abingdon, UK) micro analytical device, at the National and Kapodistrian University of Athens. At the Natural History Museum of London, further analyses and mapping were performed with a JEOL 5900LV (JEOL USA, Inc.: Peabody, MA, USA), equipped with an Energy Dispersive $X$-ray (EDX) and a Wavelength Dispersive X-ray (WDX). Electron microprobe analyses (EMPA) were carried out using the Jeol JXA 8200 Superprobe WD/ED combined microanalyzer at the University of Lausanne. Operating conditions were an accelerating voltage of $15 \mathrm{kV}$, beam current of $20 \mathrm{nA}$, and beam diameter of $1 \mu \mathrm{m}$. Counting times of $20 \mathrm{~s}$ for the peak and $10 \mathrm{~s}$ for the background on both sides of the peak were used for all elements. Overlap and matrix corrections were carried out following the established protocol and software in the laboratory. 


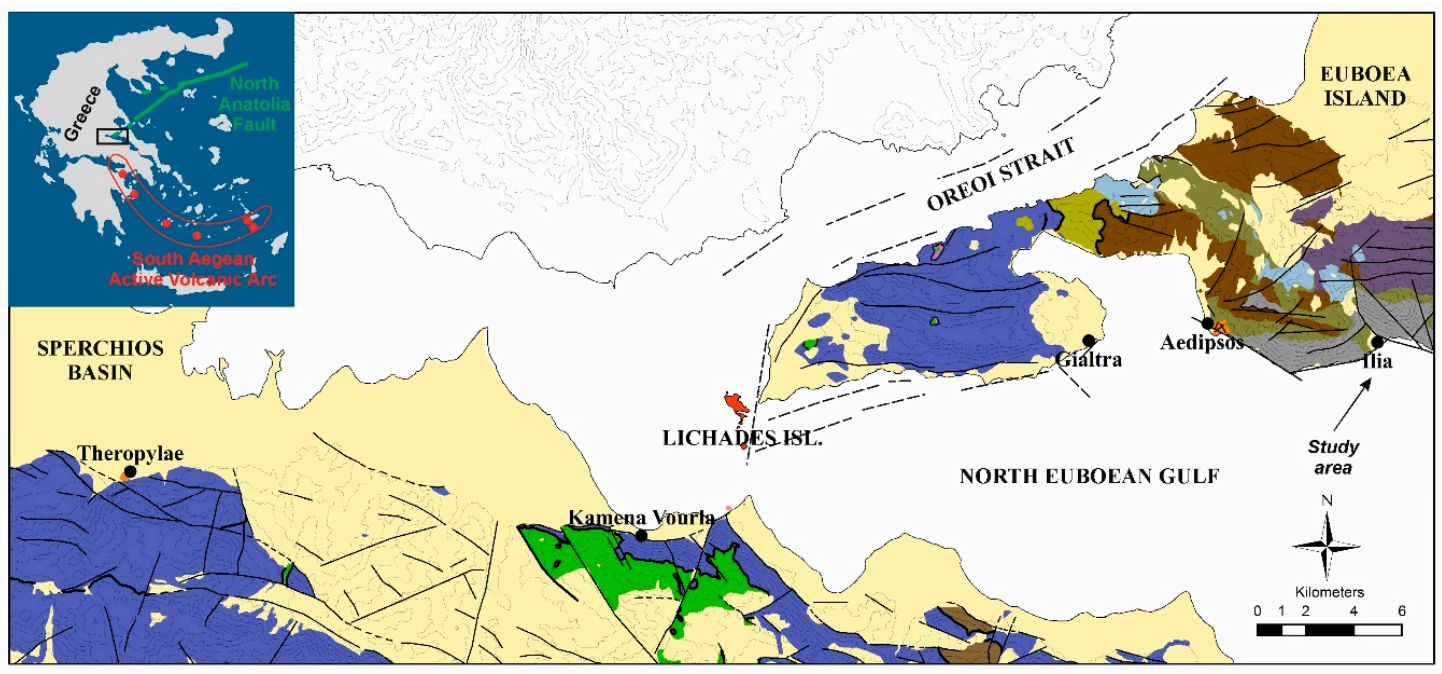

\section{LEGEND}

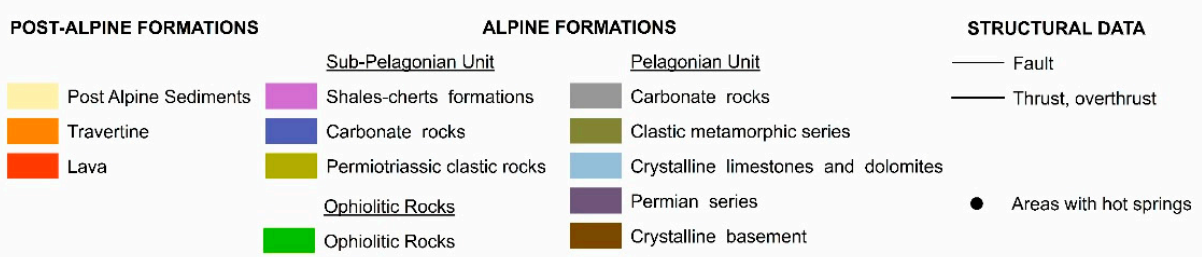

Figure 1. Simplified geological map of Northern Euboea island and neighboring area of Sperchios (mainland; modified from [69]).
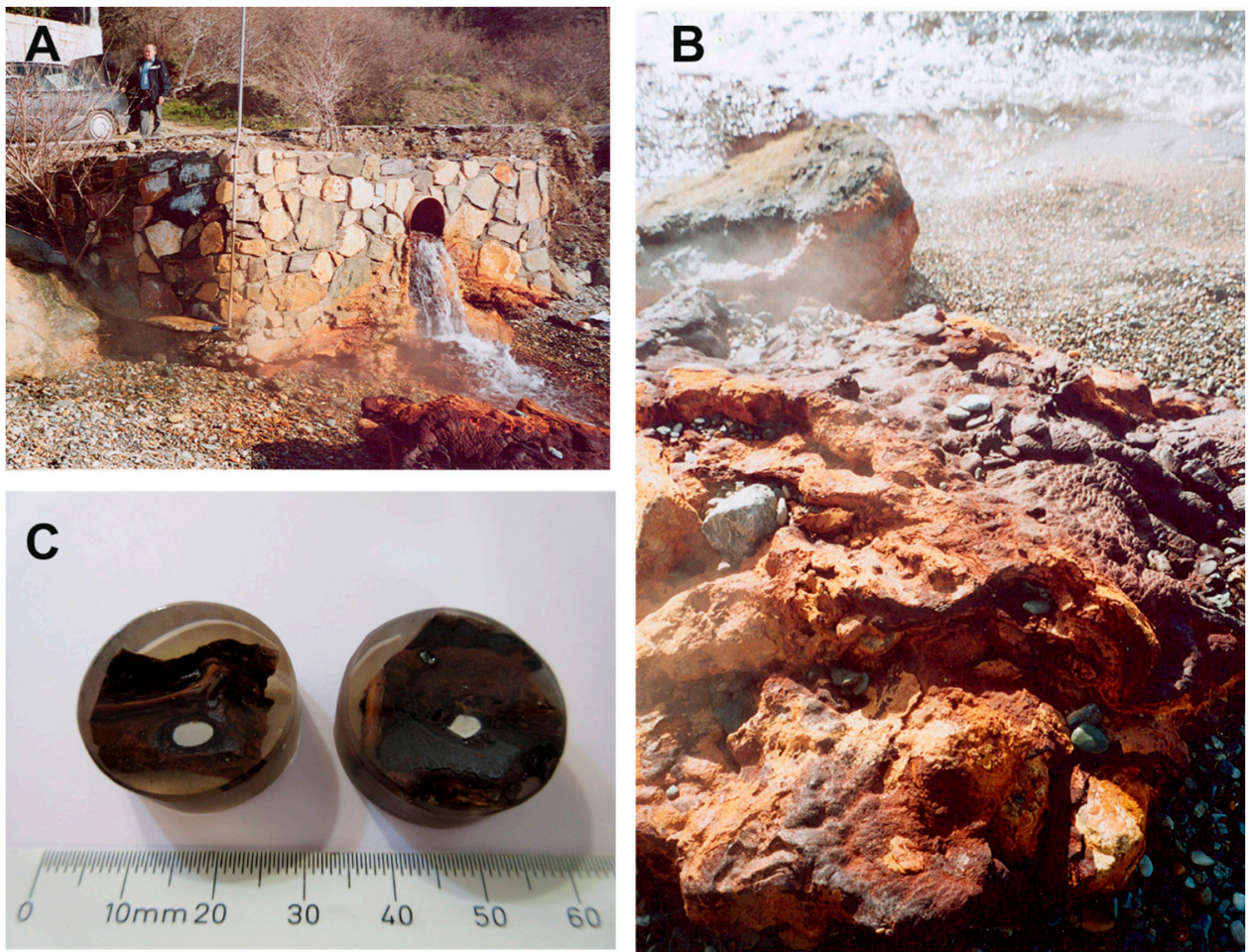

Figure 2. Iron-rich thermogenic travertines from Ilia: (A) Ilia hot spring. The Fe-rich thermogenic travertine deposits at the point where the pipe from the borehole vents the hot water. Local authorities remove the depositions, in order to avoid clogging of the spring; (B) Laminated Fe-rich travertine from Ilia; (C) Two polished sections including two different iron nodules and the hosting travertine. 
In addition, spot XRD analysis was done with Micro-X-ray diffraction, with an Inel Curved Position Sensitive Detector (PSD) and a high brightness X-ray source, at the Natural History Museum of London.

\section{Results}

Several metallic grains of native iron were identified in the iron-rich thermogenic travertine deposit from the Ilia area, northwestern Euboea Island (Greece). The biggest grains of native iron are two spherical nodules visible even with the naked eye and whose diameters are 0.4 and $0.45 \mathrm{~cm}$, respectively (Figures $2 \mathrm{C}$ and $3 \mathrm{~A}-\mathrm{C}$ ). Smaller grains, with angular shape (from few $\mu \mathrm{m}$ up to tens of $\mu \mathrm{m}$, Figure 3D) were also identified and studied.
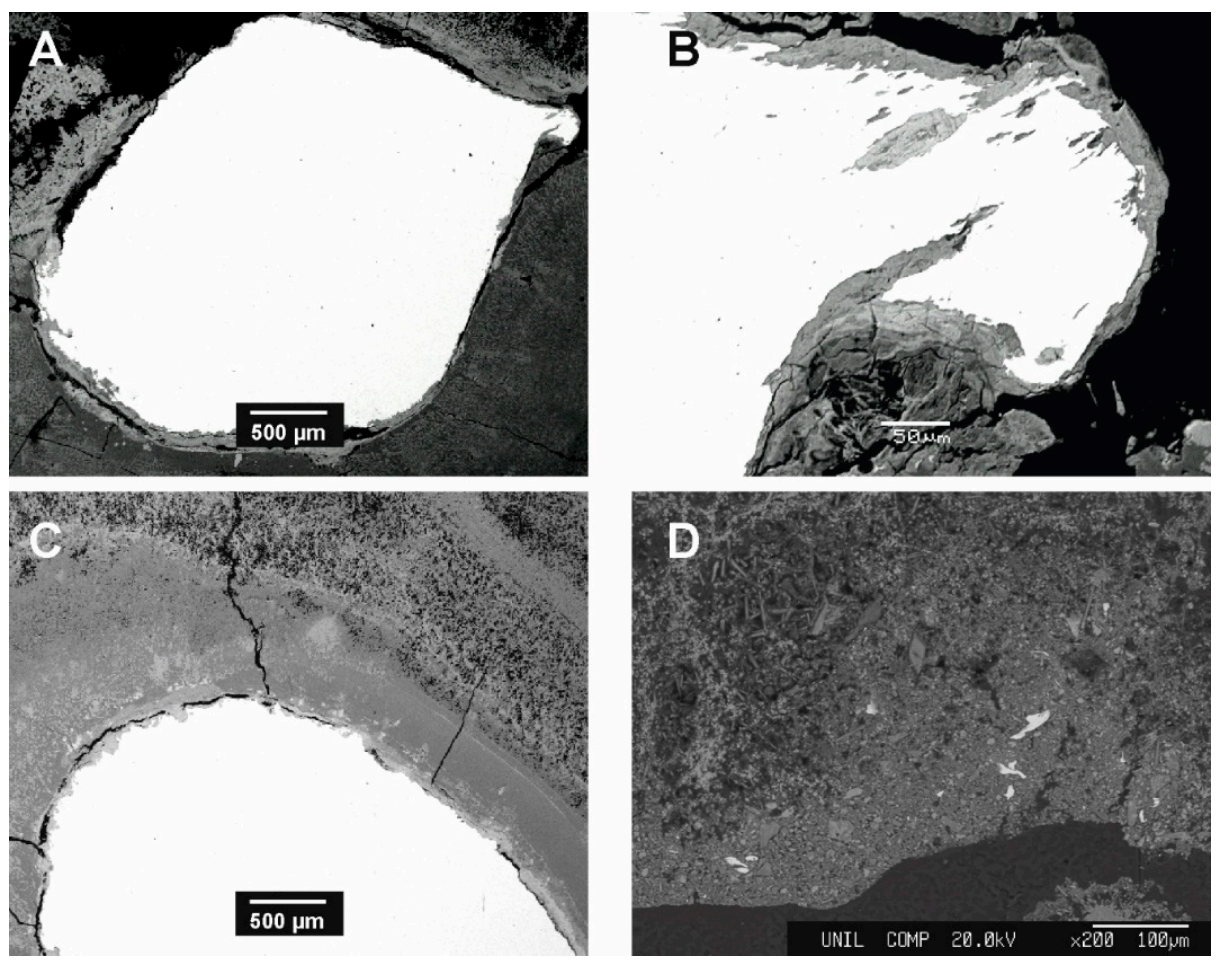

Figure 3. SEM photomicrographs: (A) Native iron nodule; (B) Oxidations were identified only at the external surface of the grains, as a result of their exposure to atmospheric conditions and water during their transfer and until their entrapment inside the travertine; $(C)$ The travertine laminae around the nodules are not interrupted, but were developed around the nodules, suggesting that the nodules were placed simultaneously with the creation of the travertine; (D) Several smaller angular pieces of native iron were found inside the travertine (from few $\mu \mathrm{m}$ up to tens of $\mu \mathrm{m}$ ).

The travertine laminae around the two spherical/ovoid nodules are not interrupted, instead they are developed smoothly around them (Figure 3C), suggesting that the nodules were placed simultaneously with the deposition of the travertine. The smaller grains (up to few $\mu \mathrm{m}$ ) are located inside the pores of the travertine (Figure 2C) in common with other metallic mineral phases like pyrite, arsenopyrite, galena, sphalerite, which are considered to be products of mechanical transport from deeper levels through the hydrothermal system [66].

The two biggest nodules of native iron are almost spherical with smooth outlines, steel gray in color, with metallic luster under the stereomicroscope and white, isotropic and with very high reflectivity under the ore microscope. Spot XRD analysis was performed on one of the nodules. The XRD pattern showed diffraction lines attributable to $\alpha$-Fe (JCPDS File No. 6-696; Figure 4). 


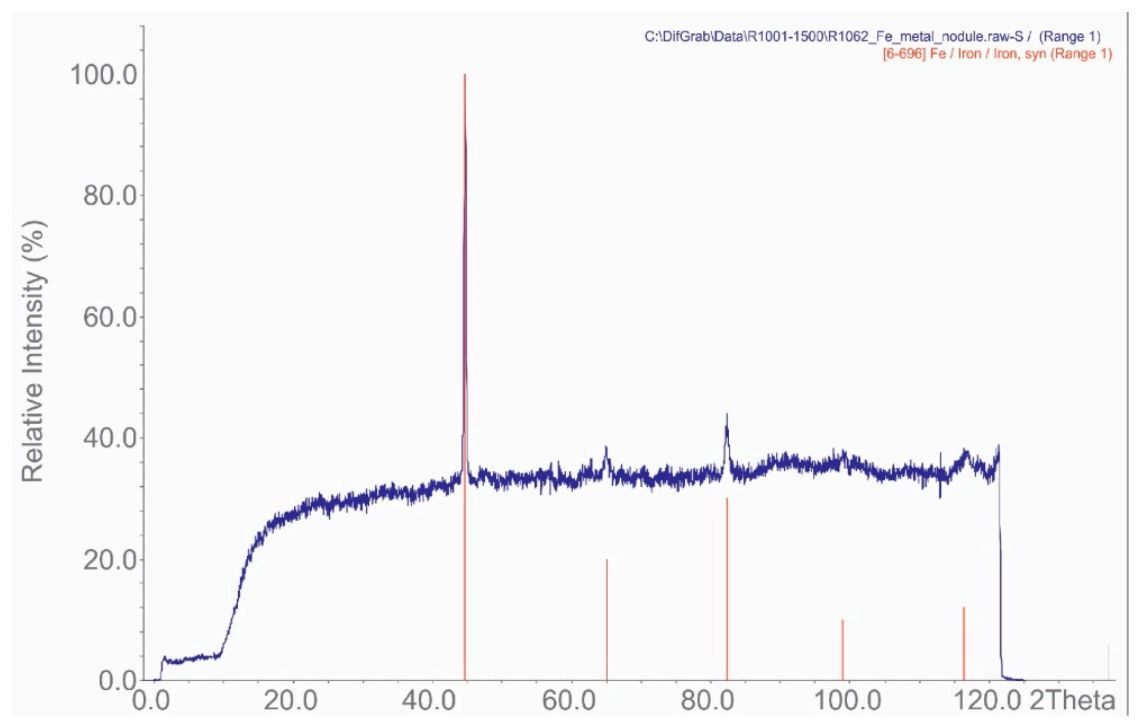

Figure 4. XRD pattern from spot XRD analysis performed on the center of one of the nodules. Diffraction lines attributable to $\alpha$-Fe (JCPDS File No. 6-696).

Analyses with SEM-EDS, -WDS and EMPA performed on both nodules and several smaller angular grains (Table 1) indicate a high purity of the grains. Except for $\mathrm{Fe}$, only a very low content of $\mathrm{Mn}(0.34-0.38 \mathrm{wt} . \%)$ and $\mathrm{Ni}(\leq 0.05 \mathrm{wt} . \%)$ was found. Microprobe analytical profiles from cores to the rims of both nodules (Table 1), as well as element mapping, revealed their chemical homogeneity (Figure 5). No chemical zonation or differentiation was found. Oxidation at the external surface of the grains was most probably the result of their exposure to atmospheric conditions and water during their transfer and until their entrapment inside the travertine (Figure 5).

Table 1. Representative EMP compositions of native iron (in element wt.\%).

\begin{tabular}{|c|c|c|c|c|c|c|}
\hline & 1 & 2 & 3 & 4 & 5 & 6 \\
\hline $\mathrm{Fe}$ & 101.18 & 101.04 & 98.45 & 98.66 & 98.79 & 98.67 \\
\hline$S$ & $\mathrm{bd}$ & $b d$ & $\mathrm{bd}$ & bd & $\mathrm{bd}$ & bd \\
\hline $\mathrm{Co}$ & $\mathrm{bd}$ & $\mathrm{bd}$ & na & na & na & na \\
\hline $\mathrm{Ni}$ & 0.05 & 0.05 & na & na & na & na \\
\hline $\mathrm{Cu}$ & bd & bd & $\mathrm{bd}$ & $\mathrm{bd}$ & $\mathrm{bd}$ & $\mathrm{bd}$ \\
\hline $\mathrm{Zn}$ & $\mathrm{bd}$ & $\mathrm{bd}$ & $\mathrm{bd}$ & $\mathrm{bd}$ & $\mathrm{bd}$ & $\mathrm{bd}$ \\
\hline As & $\mathrm{bd}$ & bd & na & na & na & na \\
\hline Se & bd & $\mathrm{bd}$ & bd & bd & $\mathrm{bd}$ & $\mathrm{bd}$ \\
\hline $\mathrm{Ag}$ & $\mathrm{bd}$ & $\mathrm{bd}$ & $\mathrm{bd}$ & $\mathrm{bd}$ & $\mathrm{bd}$ & $\mathrm{bd}$ \\
\hline $\mathrm{Sb}$ & bd & $\mathrm{bd}$ & na & na & na & na \\
\hline $\mathrm{Te}$ & $\mathrm{bd}$ & $\mathrm{bd}$ & na & na & na & na \\
\hline $\mathrm{Au}$ & $\mathrm{bd}$ & $\mathrm{bd}$ & na & na & na & na \\
\hline $\mathrm{Pb}$ & $\mathrm{bd}$ & $\mathrm{bd}$ & na & na & na & na \\
\hline $\mathrm{Bi}$ & $\mathrm{bd}$ & $\mathrm{bd}$ & na & na & na & na \\
\hline $\mathrm{Mn}$ & na & na & 0.38 & 0.35 & 0.38 & 0.34 \\
\hline $\mathrm{Cd}$ & na & na & $\mathrm{bd}$ & bd & $\mathrm{bd}$ & $\mathrm{bd}$ \\
\hline $\mathrm{Ga}$ & na & na & bd & bd & $\mathrm{bd}$ & bd \\
\hline In & na & na & $\mathrm{bd}$ & bd & bd & $\mathrm{bd}$ \\
\hline Total & 101.23 & 101.09 & 98.84 & 99.01 & 99.17 & 99.01 \\
\hline
\end{tabular}

bd = below detection limit, na $=$ not analysed. 

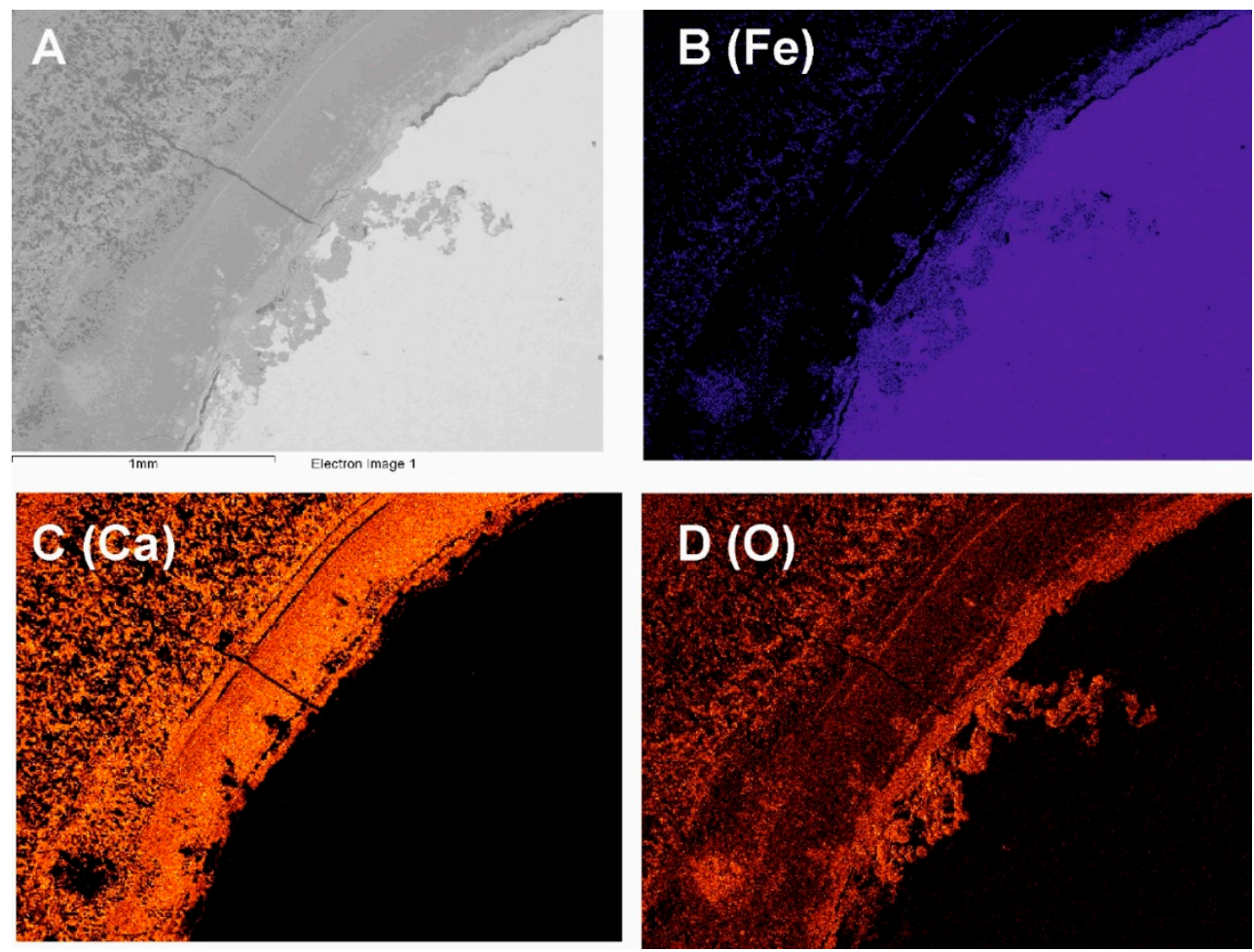

Figure 5. (A) Back-Scattered Electron Image (BSEI) of the contact between iron nodule and the Fe-rich laminated travertine; (B-D) false color BSEI results of mapping, displaying the distribution of Fe (purple), $\mathrm{Ca}$ (orange) and $\mathrm{O}$ (red).

\section{Discussion}

Ilia's hot spring is part of a large geothermal system, with hot spring manifestations in northwestern Euboea Island and the neighboring part of the mainland in eastern Central Greece, i.e., the Sperchios area [66], recognized as having one of the highest geothermal gradients in Greece, after the South Aegean Active Volcanic Arc [72]. The hydrothermal system is controlled by active tectonics, and supplied with heat by a 7-8 km deep magma chamber, with surface manifestation, the Plio-Pleistocene trachyandesitic volcanic center of Lichades. The hydrothermal fluid is a mixture of seawater and deep magmatic fluid with only limited meteoric water contribution in Euboea part [66]. Geologically, the broad area of northwestern Euboea also includes late Jurassic to early Cretaceous ophiolitic rocks, mainly metabasites and serpentinites ([57-59]; Figure 1) and Neogene-lower Pleistocene lignite lake sediments layers [60], which may be of importance for the genesis of the native iron occurrences (see below).

The hot spring of Ilia is enriched in iron (5-13.3 mg/L) compared to the other hot springs of the hydrothermal system [66]. The spring displays a water temperature in the range from 61 to $63.7^{\circ} \mathrm{C}$ and $\mathrm{pH}$ from 5.9 to 6.4 [66] and is degassing mainly $\mathrm{CO}_{2}$ [73]. Kanellopoulos et al. [66] presented considerable geochemical and mineralogical evidence supporting the magmatic contribution to the hydrothermal system.

Accordingly, Ilia's thermogenic travertine has extreme enrichment in iron (up to 28.8\%), arsenic (up to $1.8 \%$ ) and Rare Earth Elements (REE) compared to the other thermogenic travertines around the world $[66,68]$. The main mineral phases are an amorphous hydrous ferric oxyhydroxide phase, identified as ferrihydrite, aragonite and calcite [66,69], creating a laminated to banded iron-rich travertine by biotic and abiotic processes (Figure 2C; [67]). Except for native iron, previous studies $[66,68]$ have identified and documented the presence of several mineral phases including sulfides such as pyrite, arsenopyrite, galena, chalcopyrite, sphalerite and stibnite, native elements such as $\mathrm{Pb}$ and $\mathrm{Ni}$, alloys such 
as $\mathrm{Ni}-\mathrm{Co}-\mathrm{Cu}-\mathrm{Sn}, \mathrm{Au} \pm \mathrm{Cu}-\mathrm{Ag}$ and other mineral phases such as awaruite, fluorite and REE-bearing phases, which are syngenetically enclosed as clastic grains within the pores of travertine.

The shape and mineral chemistry of the studied native iron grains suggest that they did not form in situ, but they are products of a deeper environment and they were transferred by the hydrothermal fluid, as Kanellopoulos et al. [66] suggested for most of the metallic minerals enclosed in the travertines of the system.

The question here is, what is the origin of the ultra-pure native iron grains of Ilia? We examine the following scenarios for the native iron formation: (a) meteoritic, (b) anthropogenic contamination, (c) kimberlite- and diamond-related, (d) magmatic immiscibility in basaltic rocks (e) magmatic-hydrothermal formation in active geothermal fields (f) in chromitites and ophiolitic rocks (e.g., serpentinization).

(a) There is no evidence for a meteorite fall in the area and most importantly, the very low $\mathrm{Ni}$ concentration $(\leq 0.05 \mathrm{wt} . \%)$ in Ilia's native iron led to the exclusion of the scenario of extraterrestrial origin.

(b) Anthropogenic contamination is always a possibility, but we strongly believe this is not the case for Ilia. The two main nodules with diameter 0.4 and $0.45 \mathrm{~cm}$ were identified during the cutting process of the samples. A series of several samples were created from the same rock formation and several additional from other thermogenic travertines, but no such grains were identified in other travertine samples, neither from Ilia nor from other locations and all the samples were processed in exactly the same way. In addition, a variety of other native metals $(\mathrm{Pb}, \mathrm{Ni}, \mathrm{Cu})$ and alloys $(\mathrm{Ni}-\mathrm{Co}-\mathrm{Cu}-\mathrm{Sn}, \mathrm{Au} \pm \mathrm{Cu}-\mathrm{Ag})$ were found in other samples from Ilia and travertines from other locations, belonging to the Euboea-Sperchios hydrothermal system $[66,68]$ demonstrating the occurrence of in-situ metal formation. Additionally, it must be mentioned that metals produced for human consumption are not pure $\mathrm{Fe}$, but they typically contain a specific mix of elements in order to achieve better and specific properties [74].

(c) Native iron has been reported in kimberlites and diamonds. Jacob et al. [75] suggested that local and transient reducing conditions in a microenvironment result from the production of hydrogen when diamond grows from a methane-dominated fluid [76]. However, the absence of kimberlites and diamond in the greater area, and their incompatibility with the geological setting of the study area, exclude that scenario also. Additionally, Kaminsky [43] showed that the kimberlite- and diamond-related native iron grains present complex and variable compositions including $\mathrm{Cr}\left(1.13-2.37 \mathrm{wt} . \% \mathrm{Cr}_{2} \mathrm{O}_{3}\right)$, as well as $\mathrm{Ni}(0.28-0.40 \mathrm{wt} . \% \mathrm{NiO}), \mathrm{Mg}(0.16-0.94 \mathrm{wt} . \%$ $\mathrm{MgO}), \mathrm{Mn}(0.17-0.47 \mathrm{wt} . \% \mathrm{MnO}), \mathrm{Ti}\left(0.02-0.12 \mathrm{wt} . \% \mathrm{TiO}_{2}\right)$ and $\mathrm{Al}\left(0.09-0.27 \mathrm{wt} . \% \mathrm{Al}_{2} \mathrm{O}_{3}\right)$.

(d) Some of the most well-known and documented occurrences of native iron are in basalts; more specifically, in three basalt fields around the world (Bühl basalt, Kessel, Germany, Disko Island, Greenland and Khungtukun intrusion, Maimecha-Kotui magmatic province in northern Siberian, Russia). In all cases, the occurrences of reduced Fe have been attributed to basaltic magma intrusion into carbon-bearing sedimentary rocks (graphite, coal, shale, [25,52,77]). According to Kamenetsky et al. [27] the creation of native iron is due to magmatic immiscibility (i.e., unmixing of melt phases), which begins when a melt reaches a composition where its Gibbs free energy is higher than that of paired melts whose compositions equal the precursor homogeneous melt. Native iron in Khungtukun (Russia) occurs as disseminated individual spherical nodules throughout the basaltic rocks, having ovoid and spherical shaped inclusions in the silicate minerals. According to Kamenetsky et al. [27] that specific shape, i.e., drop- and bleb-like shape is evidence that strongly indicates that native Fe crystallized from a metallic liquid at the temperature of the basaltic liquid, which is below the solidus of pure iron $\left(1538^{\circ} \mathrm{C}\right)$. Carbon, provided by assimilated host local coal-bearing sedimentary rocks, played the role of the main fluxing and reducing agent reducing the magma-derived iron and depressed the liquid temperature. In agreement with Kamenetsky et al. [27], Howarth et al. [52] also suggested that primary native $\mathrm{Fe}$ is a rare crystallizing phase from terrestrial basaltic magmas, requiring highly reducing conditions. Reducing conditions in basaltic magmas can be achieved 
through assimilation of carbonaceous crustal material, such as coal beds or carbonaceous black shales, which lead to formation of an immiscible, molten, C-rich, native Fe alloy liquid in all known occurrences of native iron in basalts. Also, if this liquid also contains sufficient sulfur, it can undergo further division into conjugate $\mathrm{Fe}-\mathrm{C}$-rich and $\mathrm{Fe}-\mathrm{S}$-rich immiscible melts that can effectively scavenge highly siderophile elements such as $\mathrm{Au}, \mathrm{Ni}$ and $\mathrm{Cu}$. It should be emphasized here that similar elements are also found in Ilia travertine as transferred grains from deep-seated sources [66]. In addition, the lignite layers found in the area [60] could play the role of the fluxing and reducing agent of the magma-derived iron and the decrease of the liquid temperature. However, the absence of basaltic rocks does not support a hypothesis of Ilia native iron blebs formation by magma immiscibility at depth, i.e., that it is later transport via hydrothermal processes to the surface. Additionally, electron microprobe analyses of native iron from basalt at Ovifak, Disko Island, Greenland, Bühl basalt, Kessel, Germany and Khungtukun intrusion, Maimecha-Kotui magmatic province in northern Siberia revealed the presence of Co (0.03-0.7 wt.\%), Ni (0.2-2.5 wt.\%) and $\mathrm{Cu}(0.02-0.65$ wt.\%) [52]. This strongly contrasts with the composition of Ilia native iron grains that contain only $\mathrm{Mn}(0.34-0.38 \mathrm{wt} . \%)$ and $\mathrm{Ni}$ up to 0.05 wt. $\%$ and concentrations of $\mathrm{Cu}$ and Co below the detection limit, weakening even further the scenario of iron blebs by magma immiscibility, in our case.

(e) In active geothermal systems, native iron has only been found in Kuril Islands, Russia, in two environments: Firstly, within a geothermal borehole of the Baranskii hydrothermal system, Iturup Island, where spherical nodules of native iron are interpreted to have been formed by injection into metasomatites of a "dry" recovered fluid having high temperature and originated from great depth $[49,50]$. Rychagov et al. [78,79] suggested that native iron globules, which are similar to those found in Ilia, are sourced from cooling igneous bodies from depths of $>1.5-2 \mathrm{~km}$ and are transported towards the surface by reduced, gas-rich fluids at temperatures of $>500-600{ }^{\circ} \mathrm{C}$. On the contrary, cool hydrothermal fluids and exhausted thermal waters have no capacity to transport native iron. Native iron grains were also reported by Yudovskaya et al. [51] from high-temperature active fumaroles of the Kudryavy volcano, Iturup Island, in association with several other phases (e.g., native elements, oxides, sulfides, etc.). At Kudryavy, native iron has been precipitated together with other transition metals as a result of gas transport and disproportionation reactions combined with a drop-in temperature along the reaction path [51]. Gas transport took place from a slightly reduced (near the NNO buffer), high-temperature and low-density fluid. Nonequilibrium coexistence of reduced and oxidized phases of the transition metals are characteristic of the high-temperature stages at Kudryavy [51].

(f) Finally, native iron has been documented in ophiolitic rocks such as serpentinizated dunites, peridotites, serpentinites and in associated chromitites, in several cases such as Josephine, U.S.A. [35], Sanbagawa belt, central Japan [36], Maqsad ophiolite, Oman [37], the Balangero area, Italy [38], Luobusa ophiolite, southern Tibet [3,39,40], Ray-Iz ophiolite, Polar Urals [41] and the region neighboring the study area, Skyros island, Greece [42]. In Luobusa ophiolite, southern Tibet, native iron occurs in two forms in the chromitites, as small round nodular intergrowths and as anhedral masses of acicular crystals. The composition of these grains is close to $100 \% \mathrm{Fe}$, although some have minute amounts of Mn (0.91 to $1.82 \mathrm{wt} . \%)$ and $\mathrm{Si}$ (0.17 to $0.65 \mathrm{wt.} \%$ ) [39]. This closely resembles the native iron grains of Ilia, which are also present in two shapes (round nodules and angular grains), and their mineral composition also contains Mn (0.34 to 0.38 wt.\%), but very low $\mathrm{Ni}(\leq 0.05 \mathrm{wt} . \%)$. Bai et al. [39] suggest that Fe-Ni and $\mathrm{Fe}-\mathrm{Co}$ alloys and native $\mathrm{Fe}$ and $\mathrm{Ni}$ in the Luobusa chromitites are secondary minerals formed by alteration of PGE-bearing sulfides. Robinson et al. [3], based on the shape and composition of the inclusions in the native $\mathrm{Fe}$, concluded that most probably, they represent immiscible silicate liquids that underwent partial crystallization upon cooling. They proposed that it is unlikely all of the native elements and alloys in the Luobusa chromitites could have formed by secondary processes. However, it is equally unlikely that they are primary minerals in the sense of having 
crystallized from the melt that formed the chromitites. The chromitites must have formed under hydrous, oxidizing conditions. Therefore, Robinson et al. [3] argue that the native elements, PGE alloys and ultra-high pressure minerals are xenocrysts derived from deep-mantle sources. In many cases, the presence of native iron in layered intrusion and ophiolitic rocks has been associated with the serpentinization processes, e.g., at the Muskox intrusion, Nunavut-Canada, where native iron, native copper, awaruite, wairauite and magnetite were documented in serpentinized lizardite [30]; at Josephine, Oregon-USA. where native iron was documented in late, low temperature serpentine veins, cross-cutting serpentinized harzburgite [35]; at the Kachkanarskii massif, Russia, where native iron, nickel-iron alloy, wairauite and awaruite were documented in ore-olivinites [33]; and at Balangero, Italy where native iron with minor amounts of $\mathrm{Ni}, \mathrm{As}, \mathrm{Co}$ and sometimes $\mathrm{Cu}$ was documented in serpentinites [38]. Sakai and Kuroda [36] documented native iron in the serpentine vein of the second stage of serpentinization in dunites, from the ultramafic masses in the Sanbagawa belt, central Japan. In that case, the native iron has ovoidal and irregular shapes and is surrounded by magnetite. The native iron from the Sanbagawa belt incorporates $\mathrm{Ni}(0.26-2.03 \mathrm{wt} . \%)$ and $\mathrm{Co}(0.26-2.78 \mathrm{wt} . \%)$ and is deficient in $\mathrm{Cu}$ and S. Sakai and Kuroda [36] argue that the formation of native metals in serpentinites is not fully explained. At the same time, they suggested that during serpentinization, the iron is released from olivine, leading to the creation of magnetite. The serpentinization of olivine also produces hydrogen gas as indicated by the following reaction [30]:

$$
6 \mathrm{Mg}_{1.5} \mathrm{Fe}_{0.5} \mathrm{SiO}_{4}+7 \mathrm{H}_{2} \mathrm{O}=3 \mathrm{Mg}_{3} \mathrm{Si}_{2} \mathrm{O}_{5}(\mathrm{OH})_{4}+\mathrm{Fe}_{3} \mathrm{O}_{4}+\mathrm{H}_{2}
$$

Olivine Serpentine Magnetite

In turn, the hydrogen gas could reduce magnetite to native iron and sulfides such as pentlandite and chalcopyrite to awaruite, native copper. The serpentinization process is a rather low temperature process where the upper stability of serpentine is $\sim 450{ }^{\circ} \mathrm{C}$ [80], but it is uncertain if the dissociation of magnetite is affected under such temperatures. Ophiolitic rocks are present in the northwestern Euboea Island, as well as in the neighboring part of the mainland in eastern Central Greece, i.e., Sperchios area, where the hydrothermal system also extends. In Northern Euboea, the ophiolites include mainly metabasites and serpentinites [58-60]; however little is known about their mineralogy and origin. Although the outcrops are very limited in Euboea island, Kanellopoulos and Argyraki [81] and Kanellopoulos and Mitropoulos [82], who studied the soils and groundwaters, respectively, identified their geochemical signature in great areas of northwestern Euboea. In the neighboring island of Skyros, Tarkian et al. [42] identified native iron at ophiolitic rocks associated with chromitites. The ophiolite of Skyros also includes serpentinized harzburgites, gabbroic rocks, dolerites, tholeiitic basaltic lavas, rodingites, as well as ophicalcites [83,84].

Based on all the above-mentioned data, we suggest here two possible scenarios concerning the origin of Ilia's native iron. The first one involves a two-step process: Native iron is of magmatic/hydrothermal origin, i.e., its source could be the magmatic chamber or a peripheral cooling igneous body beneath the Ilia area, and it was formed during the early stages of the geothermal evolution in the area. It has been transported by a reduced gas-rich, and high temperature fluid through permeable structural zones towards the surface, and was precipitated at shallow depths, in a manner as described from the Baranskii hydrothermal system by Rychagov et al. [78,79]. Later on, and during the recent active geothermal activity in the area, it was remobilized and mechanically transported by the hydrothermal fluids and deposited together with the other metallic phases in the travertine layers. Alternately, but not in favour, Ilia's native iron originates from deep ophiolite rocks and/or chromitites possibly associated with serpentinization processes. This scenario could explain the presence of other mineral phases at the Ilia thermogenic travertine, such as other native elements like 
$\mathrm{Ni}$, alloys like $\mathrm{Ni}-\mathrm{Co}-\mathrm{Cu}-\mathrm{Sn}$, and other mineral phases like awaruite, which have been documented in ophiolitic rocks elsewhere. However, ophiolitic rocks are not exposed in the close neighboring area and are not located in the deep geothermal boreholes in the NW Euboea area. A remobilization and hydrothermal transport of up to $4 \mathrm{~mm}$ large grains of native iron from great depths to the surface seems to be not possible, comparing relative densities between the iron nodules and the hydrothermal fluid.

\section{Conclusions}

Ilia's hot spring represents a terrestrial active mineralizing hydrothermal system associated with ore-bearing travertines, located at the western extremity of the Northern Anatolia Fault and at the back-arc position of South Aegean Active Volcanic Arc.

Within the Ilia iron-rich thermogenic travertine, a new occurrence of ultra-pure native iron grains (with only up to $0.38 \mathrm{wt} . \% \mathrm{Mn}$ and $\leq 0.05 \mathrm{wt} . \% \mathrm{Ni}$ ) accompany previously described metal-bearing minerals such as sulfides, native elements ( $\mathrm{Pb}$ and $\mathrm{Ni}$, alloys such as $\mathrm{Ni}-\mathrm{Co}-\mathrm{Cu}-\mathrm{Sn}, \mathrm{Au} \pm \mathrm{Cu}-\mathrm{Ag}$ ), awaruite and REE-bearing phases. In common with the above metallic phases, it is here suggested that native iron was probably a product from a deep environment that was transferred by the hydrothermal fluids to the surface. Regarding the origin of the native iron grains, after evaluating all the possible environments, where native iron could be form and based on the until now available geological data of the study area, we suggest two possible scenarios: (i) Ilia's native iron originates from the magmatic chamber or a peripheral cooling igneous body, and was transferred from high-temperature and reduced gas-rich fluids, and deposited along with other metals in permeable structural zones, at near surface levels. Subsequently, native iron was remobilized and mechanically transported from lower temperature active hydrothermal fluids and precipitated within the thermogenic travertine on the surface. (ii) An alternative origin for the native iron could involve remobilization and mechanical transfer from deep unexposed serpentinites and/or chromitites bodies; however, this is less realistic.

Author Contributions: C.K. performed the sampling and participated in the elaboration of all the laboratory analyses, the interpretation of the results, coordinated the research, made the graphical presentation and wrote the paper. E.V.-J. participated in the Spot XRD and SEM-WDS analyses and the interpretation of the results. P.V. and C.S. participated in the interpretation of the results. R.M. participated in the EMPA analyses. C.M. participated in the SEM-EDS analyses and assisted with formatting the manuscript. P.M. participated in the SEM-EDS analyses and the interpretation of the results.

Funding: This research received no external funding.

Conflicts of Interest: The authors declare no conflict of interest.

\section{References}

1. Okrugin, A.V.; Oleinikov, B.V.; Zayakina, N.V.; Leskova, N.V. Native metals in trap rocks of the Siberian platform. Zap. Vses. Mineral. Obshchestva 1981, 110, 186-204. (In Russian)

2. Dekov, V.M.; Arnaudov, V.; Munnik, F.; Boycheva, T.B.; Fiore, S. Native aluminum: Does it exist? Am. Mineral. 2009, 94, 1283-1286. [CrossRef]

3. Robinson, P.T.; Bai, W.-J.; Malpas, J.; Yang, J.-S.; Zhou, M.-F.; Fang, Q.-S.; Hu, X.-F.; Staudigel, H. Ultra-high pressure minerals in the Luobusa Ophiolite, Tibet, and their tectonic implications. Geol. Soc. Lond. Spec. Publ. 2004, 226, 247-271. [CrossRef]

4. Dekov, V. Native nickel in the TAG hydrothermal field sediments (Mid-Atlantic Ridge, $26^{\circ} \mathrm{N}$ ): Space trotter, guest from mantle, or a widespread mineral, connected with serpentinization. J. Geophys. Res. 2006, 111. [CrossRef]

5. Fulignati, P.; Sbrana, A. Presence of native gold and tellurium in the active high-sulfidation hydrothermal system of the La Fossa volcano (Vulcano, Italy). J. Volcanol. Geotherm. Res. 1998, 86, 187-198. [CrossRef]

6. Taran, Y.A.; Bernard, A.; Gavilanes, J.-C.; Africano, F. Native gold in mineral precipitates from high-temperature volcanic gases of Colima volcano, Mexico. Appl. Geochem. 2000, 15, 337-346. [CrossRef]

7. Hannington, M.D.; Thompson, G.; Rona, P.A.; Scott, S.D. Gold and native copper in supergene sulphides from the Mid-Atlantic Ridge. Nature 1998, 333, 64-66. [CrossRef] 
8. Distler, V.V.; Yudovskaya, M.A.; Mitrofanov, G.L.; Prokofev, V.Y.; Lishnevskii, E.N. Geology, composition, and genesis of the Sukhoi Log noble metals deposit, Russia. Ore Geol. Rev. 2004, 24, 7-44. [CrossRef]

9. Klöck, W.; Palme, H.; Tobschall, H.J. Trace elements in natural metallic iron from Disko Island, Greenland. Contrib. Mineral. Petrol. 1986, 93, 273-282. [CrossRef]

10. Morgan, J.; Anders, E. Chemical composition of Earth, Venus, and Mercury. Proc. Natl. Acad. Sci. USA 1980, 77, 6973-6977. [CrossRef] [PubMed]

11. Alfe, D.; Gillan, M.J.; Vocadlo, L.; Brodholt, J.; Price, G.D. The ab initio simulation of the Earth's core. Philos. Trans. R. Soc. A 2002, 360, 1227-1244. [CrossRef] [PubMed]

12. Greenwood, N.N.; Earnshaw, A. Chemistry of the Elements; Butterworth-Heinemann: Amsterdam, The Netherlands, 1997.

13. Ayres, R.U.; Ayres, L.W.; Masini, A. An application of exergy accounting to five basic metal industries. In Sustainable Metals Management; Gleich, A., Ayres, R.U., Gößling-Reisemann, S., Eds.; Springer: Dordrecht, The Netherlands, 2006.

14. Buchwal, V.F. The mineralogy of iron meteorites. Philos. Trans. R. Soc. Lond. A 1977, 286, 453-491. [CrossRef]

15. Anthony, J.; Bideaux, R.; Bladh, K.; Nichols, M. Handbook of Mineralogy; Mineral Data Publishing: Tucson, Arizona, 1990.

16. Bird, J.M.; Weathers, M.S. Native iron occurrences of Disko Island, Greenland. J. Geol. 1977, 85, $359-371$. [CrossRef]

17. Pedersen, A.K. Armalcolite-bearing Fe-Ti oxide assemblages in graphite-equilibrated sialic volcanic rocks with native iron from Disko, central West Greenland. Contrib. Mineral. Petrol. 1981, 77, 307-324. [CrossRef]

18. Goodrich, C.A. Phosphoran pyroxene and olivine in silicate inclusions in natural iron-carbon alloy, Disko Island, Greenland. Geochim. Cosmochim. Acta 1984, 48, 1115-1126. [CrossRef]

19. Goodrich, C.A.; Bird, J.M. Formation of iron-carbon alloys in basaltic magma at Uivfaq, Disko Island: The role of carbon in mafic magmas. J. Geol. 1985, 934, 75-492. [CrossRef]

20. Hornstein, F.F. Mitteilung fiber das Vorkommen yon makroskopischen Einschliissen gediegenen Eisens in Basalt aus der Gegend von Cassel. Zentralbl Mineral. 1907, 1907, 276-279.

21. Medenbach, O.; El Goresy, A. Ulvospinel in native ironbearing assemblages and the origin of these assemblages in basalts from Ovifak, Greenland, and Buhl, Federal Republic of Germany. Contrib. Mineral. Petrol. 1982, 80, 358-366. [CrossRef]

22. Ryabov, V.V.; Pavlov, A.L.; Lopatin, G.G. Native Iron of the Siberian Traps; Nauka Publisher: Novosibirsk, Russia, 1985. (In Russian)

23. Oleinikov, B.V.; Okrugin, A.V.; Tomshin, M.D.; Levashov, V.K.; Varganov, A.S.; Kopylova, A.G.; Pankov, Y.U. Native Iron Formation in Platform Basic Rocks; Yakutian Scientific Center, Siberian Branch of the Russian Academy of Sciences: Yakutsk, Russia, 1985. (In Russian)

24. Ryabov, Y.Y.; Anoshin, G.N. Platinum-iron metallization in intrusive traps of the Siberian Platform. Geol. Geofiz. 1999, 40, 162-174.

25. Ryabov, V.V.; Lapkovsky, A.A. Native iron (-platinum) ores from the Siberian Platform trap intrusions. Aust. J. Earth Sci. 2010, 57, 707-736. [CrossRef]

26. Ryabov, V.V.; Lapkovsky, A.A. Unique polymineral association of Co-Ni and noble metal phases in gabbro-dolerite of the Dzhaltul trap intrusion (Siberian Platform). Dokl. Earth Sci. MAIK Nauka/Interperiodica 2010, 434, 1325-1329. [CrossRef]

27. Kamenetsky, V.S.; Charlier, B.; Zhitova, L.; Sharygin, V.; Davidson, P.; Feig, S. Magma chamber-scale liquid immiscibility in the Siberian Traps represented by melt pools in native iron. Geology 2013, 41, 1091-1094. [CrossRef]

28. Ryabov, V.V.; Shevko, A.Y.; Gora, M.P. Intrusive Complexes of the Norilsk Region. In Trap Magmatism and Ore Formation in the Siberian Norilsk Region; Springer: Dordrecht, The Netherlands; London, UK, 2014; pp. 93-206.

29. Pernet-Fisher, J.F.; Day, J.M.; Howarth, G.H.; Ryabov, V.; Taylor, L.A. Atmospheric outgassing and native-iron formation during carbonaceous sediment-basalt melt interactions. Earth Planet. Sci. Lett. 2017, 460, 201-212. [CrossRef]

30. Chamberlain, A.; McLeod, C.R.; Traill, R.J.; Lachance, G.R. Native metals in the Muskox intrusion. Can. J. Earth Sci. 1965, 2, 188-215. [CrossRef]

31. Clark, A.H. Preliminary observation on chromian mackinawite and associated native-iron, Mina do Abessedo, Vinhais, Portugal. Neues Jahrb. Mineral. Abh. 1969, 6, 282-288. 
32. Grudinin, M.I.; Sekerin, A.P. Native iron in ultrabasites of Shamanskii massif. Dokl. Akad. Nauk SSSR 1979, $245,1208-1210$.

33. Borisenko, L.F.; Begizov, V.D.; Kurilenko, N.M. Native iron in ore-olivinites of Kachkanarskii massif. Dokl. Akad. Nauk SSSR 1982, 264, 947-950.

34. Skripnichenko, V.A.; Cherepanov, A.A.; Grib, V.P.; Pashkevich, S.M. Moissanite and native iron in serpentinites of Vetrenii belt. Dokl. Akad. Nauk SSSR 1982, 267, 1453-1455.

35. Harding, D.J.; Bird, J.M.; Bassett, W.A. The origin of awaruite and native iron in the Josephine peridotite, SW Oregon and NW California. EOS Trans. Amer. Geophys. Union 1982, 63, 455.

36. Sakai, R.; Kuroda, Y. Native iron and the associated minerals from the ultramafic masses in the Sanbagawa belt, central Japan. J. Jpn. Assoc. Min. 1983, 78, 467-478. [CrossRef]

37. Lorand, J.P. A New Occurrence of Native Iron in a Serpentinized Mantle Peridotite-Maqsad, Sumail Massif, Semail Ophiolite (Southern Oman). Comptes Rendus De L Academie Des Sciences Serie II 1987, 304, 703-706.

38. Rossetti, P.; Zucchetti, S. Occurrence of native iron, Fe-Co and Ni-Fe alloys in the serpentinite from the Balangero asbestos mine (Western Italian Alps). Ofioliti 1988, 13, 43-56.

39. Bai, W.; Robinson, P.T.; Fang, Q.; Yang, J.; Yan, B.; Zhang, Z.; Hu, X.-F.; Zhou, M.-F.; Malpas, J. The PGE and base-metal alloys in the podiform chromitites of the Luobusa ophiolite, southern Tibet. Can. Mineral. 2000, 38, 585-598. [CrossRef]

40. Bai, W.J.; Yang, J.S.; Fang, Q.S.; Yan, B.G.; Zhang, Z.M.; Ren, Y.F.; Shi, N.C.; Ma, Z.S.; Dai, M.Q. Some native metals from ophiolitic chromitites in Tibet. Earth Sci. Front. 2004, 11, 179-187, (In Chinese with English Abstract).

41. Yang, J.; Meng, F.; Xu, X.; Robinson, P.T.; Dilek, Y.; Makeyev, A.B.; Wirth, R.; Wiedenbeck, M.; Cliff, J. Diamonds, native elements and metal alloys from chromitites of the Ray-Iz ophiolite of the Polar Urals. Gondwana Res. 2015, 27, 459-485. [CrossRef]

42. Tarkian, M.; Economou-Eliopoulos, M.; Eliopoulos, D.G. Platinum-Group Minerals and Tetraauricupride in Ophiolitic Rocks of Skyros Island, Greece. Mineral. Petrol. 1992, 47, 55-66. [CrossRef]

43. Kaminsky, F. Mineralogy of the lower mantle: A review of 'super-deep' mineral inclusions in diamond. Earth Sci. Rev. 2012, 110, 127-147. [CrossRef]

44. Sobolev, N.V.; Ephimova, E.S.; Pospelova, L.I. Native iron in Yakutian diamonds and its paragenesis. Geol. Geofiz. 1981, 22, 25-28. (In Russian)

45. Meyer, H.O.A.; McCallum, M.E. Mineral inclusions in diamonds from the Sloan kimberlites, Colorado. J. Geol. 1986, 94, 600-612. [CrossRef]

46. Hayman, P.C.; Kopylova, M.G.; Kaminsky, F.V. Lower mantle diamonds from Rio Soriso (Juina, Brazil). Contrib. Mineral. Petrol. 2005, 149, 430-445. [CrossRef]

47. Kaminsky, F.; Wirth, R.; Matsyuk, S.; Schreiber, A.; Thomas, R. Nyerereite and nahcolite inclusions in diamond: Evidence for lower-mantle carbonatitic magmas. Mineral. Mag. 2009, 73, 797-816. [CrossRef]

48. Stachel, T.; Brey, G.P.; Harris, J.W. Kankan diamonds (Guinea) I: From the lithosphere down to the transition zone. Contrib. Mineral. Petrol. 2000, 140, 16-27. [CrossRef]

49. Rychagov, S.N. Hydrothermal-magmatic systems of island arcs: The structure and stages development. In Proceedings of the International Kuril-Kamchatka Field Workshop 7 “Geothermal and Mineral Resources of Modern Volcanism Areas", Petropavlovsk Kamchatsky, Russia, 16 July-6 August 2005; pp. 117-140. (In Russian)

50. Rychagov, S.; Belousov, V.; Sandimirova, E.; Davletbayev, R. Hydrothermal ore minerals: Composition, distribution and formation conditions in a conductive geothermal environment. In Proceedings of the International Mineral Extraction from Geothermal Brines Conference, 6-8 September 2006.

51. Yudovskaya, M.A.; Distler, V.V.; Chaplygin, I.V.; Mokhov, A.V.; Trubkin, N.V.; Gorbacheva, S.A. Gaseous transport and deposition of gold in magmatic fluid: Evidence from the active Kudryavy volcano, Kurile Islands. Mineral. Depos. 2006, 40, 828-848. [CrossRef]

52. Howarth, G.H.; Day, J.M.D.; Pernet-Fisher, J.F.; Goodrich, C.A.; Pearson, D.G.; Luo, Y.; Ryabov, V.V.; Taylor, L.A. Precious metal enrichment at low-redox in terrestrial native Fe-bearing basalts investigated using laser-ablation ICP-MS. Geochim. Cosmochim. Acta 2017, 203, 343-363. [CrossRef]

53. Bi, D.; Morton, R.D.; Wang, K. Cosmic nickel-iron alloy spherules from Pleistocene sediments, Alberta, Canada. Geochim. Cosmochim. Acta 1993, 57, 4129-4136. [CrossRef] 
54. Pe-Piper, G.; Piper, D. The Igneous Rocks of Greece, the Anatomy of an Orogen; Gebruder Borntraeger: Berlin, Germany, 2002.

55. Vött, A. Relative sea level changes and regional tectonic evolution of seven coastal areas in NW Greece since the mid-Holocene. Quat. Sci. Rev. 2007, 26, 894-919. [CrossRef]

56. Jolivet, L.; Faccenna, C.; Huet, B.; Labrousse, L.; Le Pourhiet, L.; Lacombe, O.; Lecomte, E.; Burov, E.; Denèle, Y.; Brun, J.-P.; et al. Aegean tectonics: Strain localisation, slab tearing and trench retreat. Tectonophysics 2013, 597-598, 1-33. [CrossRef]

57. Katsikatsos, G.; Mettos, A.; Vidakis, M.; Bavay, P.; Panagopoulos, A.; Basilaki, A.; Papazeti, E. Geological Study of Aedipos Area-Euboea; Institute of Geology and Mineral Exploration (IGME), Geothermal Studies (P.E.C.): Athens, Greece, 1982. (In Greek)

58. Katsikatsos, G.; Mettos, A.; Vidakis, M. Geological Map of Greece in 1: 50,000, Istiea Sheet; Institute of Geology and Mineral Exploration (IGME): Athens, Greece, 1984.

59. Scherreiks, R. Platform margin and oceanic sedimentation in a divergent and convergent plate setting (Jurassic, Pelagonian Zone, NE Evvoia, Greece). Int. J. Earth Sci. 2000, 89, 90-107. [CrossRef]

60. Vakalopoulos, P.; Metaxas, A.; Xenakis, M. Research and Evaluation of Lignite Resources in Euboea Island: Northern Euboea Basin; Institute of Geology and Mineral Exploration (IGME): Athens, Greece, 2000; 35p. (In Greek)

61. Georgalas, G.C. Über den chemismus der laven der vulkane von Lichadonissia, Wromolimni und Hagios Ioannis (Kamena Wourla). Praktika Academia Athinon 1940, 15, 116-131.

62. Fytikas, M.; Giuliani, O.; Innocenti, F.; Marinelli, G.; Mazzuoli, R. Geochronological data on recent magmatism of the Aegean Sea. Tectonophysics 1976, 31, T29-T34. [CrossRef]

63. Kranis, H. Neotectonic Activity of Fault Zones in Central-Eastern Mainland Greece (Lokris). Ph.D. Thesis, National and Kapodistrian University of Athens, Athens, Greece, 1999. (In Greek with English Abstract).

64. Karastathis, V.K.; Papoulia, J.; Di Fiore, B.; Makris, J.; Tsambas, A.; Stampolidis, A.; Papadopoulos, G.A. Deep structure investigations of the geothermal field of the North Euboean Gulf, Greece, using 3-D Local Earthquake Tomography and Curie Depth Point analysis. J. Volcanol. Geotherm. Res. 2011, 206, 106-120. [CrossRef]

65. Innocenti, F.; Agostini, S.; Doglioni, C.; Manetti, P.; Tonarini, S. Geodynamic evolution of the Aegean: Constraints from the Plio-Pleistocene volcanism of the Volos-Evia area. J. Geol. Soc. Lond. 2010, 167, 475-489. [CrossRef]

66. Kanellopoulos, C.; Mitropoulos, P.; Valsami-Jones, E.; Voudouris, P. A new terrestrial active mineralizing hydrothermal system associated with ore-bearing travertines in Greece (northern Euboea Island and Sperchios area). J. Geochem. Explor. 2017, 179, 9-24. [CrossRef]

67. Kanellopoulos, C.; Thomas, C.; Xirokostas, N.; Ariztegui, D. Biotic and abiotic processes involved in the formation of banded iron travertine. In Proceedings of the 33rd International Sedimentological Association (IAS) and 16th Association des Sédimentologistes Français (ASF) Joint Meeting, Congress-Abstracts Book, Toulouse, France, 10-12 October 2017; p. 458.

68. Kanellopoulos, C. Geochemical Research on the Distribution of Metallic and Other Elements in the Cold and Thermal Groundwater, Soils and Plants in Fthiotida Prefecture and N. Euboea. Environmental Impact. Ph.D. Thesis, National and Kapodistrian University of Athens, Athens, Greece, 2011. (In Greek with English Abstract).

69. Kanellopoulos, C. Distribution, lithotypes and mineralogical study of newly formed thermogenic travertines in Northern Euboea and Eastern Central Greece. Cent. Eur. J. Geosci. 2012, 4, 545-560. [CrossRef]

70. Kanellopoulos, C. Morphological types, lithotypes, mineralogy and possible bio-mineralization processes in simple and iron-rich travertines from active thermogenic travertine-forming systems in Greece. The cases of Northern Euboea and Eastern Central Greece. In Proceedings of the 19th International Sedimentological Congress-Abstracts Book, Geneva, Switzerland, 18-22 August 2014; p. 341.

71. Gkioni-Stavropoulou, G. Hydrogeological Study of Hot and Mineral Springs of Euboean-Maliac Gulf; Institute of Geology and Mineral Exploration (IGME): Athens, Greece, 1998. (In Greek)

72. Fytikas, M.; Kolios, N. Preliminary heat flow map of Greece. In Terrestrial Heat Flow in Europe; Cermak, V., Rybach, L., Eds.; Springer: Berlin, Germany, 1979; pp. 197-205. 
73. D'Alessandro, W.; Brusca, L.; Kyriakopoulos, K.; Bellomo, S.; Calabrese, S. A geochemical traverse along the "Sperchios Basin e Evoikos Gulf" graben (Central Greece): Origin and evolution of the emitted fluids. Mar. Petrol. Geol. 2014, 55, 295-308. [CrossRef]

74. Budinski, K.G.; Labs, B. Engineering Materials: Properties and Selectioni, 9th ed.; Pearson: London, UK, 2009; ISBN 139780137128426.

75. Jacob, D.E.; Kronz, A.; Viljoen, K.S. Cohenite, native iron and troilite inclusions in garnets from polycrystalline diamond aggregates. Contrib. Mineral. Petrol. 2004, 146, 566-576. [CrossRef]

76. Thomassot, E.; Cartigny, P.; Harris, J.W.; Viljoen, K.S. Methane-related diamond crystallization in the Earth's mantle: Stable isotope evidences from a single diamond-bearing xenolith. Earth Planet. Sci. Lett. 2007, 257, 362-371. [CrossRef]

77. Bird, J.; Goodrich, C.; Wrathers, M. Petrogenesis of Uivfaq Iron, Disko Island, Greenland. J. Geophys. Res. 1981, 86, 11787-11805. [CrossRef]

78. Rychagov, S.; Koroleva, G.; Stepanov, I.; Sandimirova, E. Ore elements in the structure of geothermal resevoir: Distribution, geochemistry and mineralogy, probable sources (fundamental scientific and practical questions). In Proceedings of the World Geothermal Congress, Kyushu, Japan, 28 May-10 June 2000.

79. Rychagov, S.F.; Glavatskikh, S.N.; Sandimirova, E.I. Ore and Silicate Magnetic Pellets as Indicators of Structure and Fluid Regime, as well as Mineral and Ore Formation in the Present-Day Baranskii Hydrothermal System, Iturup Island. Geol. Ore Depos. 1996, 38, 26-34, Translated from Geologiya Rudnykh Mestorozhdenii. Vol. 3S. No. 1. 1996. pp. 31-40.

80. Früh-Green, G.; Connolly, J.; Plas, A.; Kelley, D.; Grobéty, B. Serpentinization of oceanic peridotites: Implications for geochemical cycles and biological activity. In The Subseafloor Biosphere at Mid-Ocean Ridges; Wilcock, W.D., Kelley, D.S., DeLong, E., Cary, C., Eds.; AGU Geophysical Monograph: Washington, DC, UDA, 2004; Volume 144, pp. 119-136.

81. Kanellopoulos, C.; Argyraki, A. Soil baseline geochemistry and plant response in areas of complex geology. Application to NW Euboea, Greece. Chemie der Erde-Geochemistry 2013, 73, 519-532. [CrossRef]

82. Kanellopoulos, C.; Mitropoulos, P. Geochemical effect of the rock chemistry and the anthropogenic activities on groundwater: The case of NW Euboea, Greece. Bull. Geol. Soc. Greece 2013, 47, 942-952. [CrossRef]

83. Karkalis, C.; Magganas, A.; Koutsovitis, P. Petrological, mineralogical and geochemical data from the Eohellenic ophiolitic nappe in the island of Skyros, Greece. Bull. Geol. Soc. Greece 2017, 50, 1867-1877. [CrossRef]

84. Stouraiti, C.; Patziris, I.; Vasilatos, C.; Kanellopoulos, C.; Mitropoulos, P.; Pomonis, P.; Moritz, R.; Chiaradia, M. Ophiolitic remnants from the Upper Unit of the Attic-Cycladic Crystalline Belt (Aegean, Greece): Fingerprinting geochemical affinities of magmatic precursors. Geosci. J. 2017, 7. [CrossRef] 